\title{
Cinclidotus vivesii sp. nov. (Musci, Pottiaceae) from the Iberian Peninsula
}

\author{
by
}

\begin{abstract}
A. Ederra
Departamento de Botánica, Facultad de Ciencias, Universidad de Navarra, E-31008 Pamplona. E-mail: aederra@unav.es

\section{J. Guerra}

Departamento de Biología Vegetal (Botánica), Facultad de Biología, Universidad de Murcia, E-30100 Espinardo (Murcia). E-mail: jguerra@um.es

With 1 figure
\end{abstract}

Ederra, A. \& J. Guerra (2005): Cinclidotus vivesii sp. nov. (Musci, Pottiaceae) from the Iberian Peninsula. - Nova Hedwigia 81: 471-475.

Abstract: Cinclidotus vivesii is described and illustrated as a new species from NE Spain (Iberian Peninsula). It is well distinguished by a combination of characters: rigid appearance; non-curled, lanceolate and slightly falcate leaves; leaf margins elliptical in cross section, up to 4 cells thick with the inner cells similar to the superficial ones, and confluent at the leaf apex; nerve excurrent in a mucro; and smooth laminal cells.

Key words: Cinclidotus vivesii sp. nov., Pottiaceae, taxonomy, Spain, Iberian Peninsula, aquatic mosses.

\section{Introduction}

While studying material of the genus Cinclidotus P. Beauv. for the project "Flora Briofítica Ibérica" we had the opportunity to study many samples from several Iberian herbaria. We found one specimen from northeastern Spain (BCB 35184), labelled as Cinclidotus fontinaloides (Hedw.) P. Beauv., differing in so many features from $C$. fontinaloides that it could not be assigned there. The possibility of identifying the specimen as Cinclidotus riparius (Host ex Brid.) Arn., C. aquaticus (Hedw.) Bruch \& Schimp. or other taxa which have been recorded from Spain (Casas 1991, 1995, 1996, 1999; www.einstein.uab.es 2005), was also rejected because of several 
differences between the specimen and these taxa. After studying the majority of the type species of this genus and comparing the specimen with original descriptions of all known species, we concluded that this sample is a new species of Cinclidotus.

\section{Description}

Cinclidotus vivesii A. Ederra sp. nov.

Fig. 1

Type: España. Barcelona: Berguedá, Cercs, Font Gran, 21-II-1971, J. Vives (holotype: BCB 35184, isotype: PAMP 7475).

Etymology: vivesii, dedicated (named after) to Dr. Josep Vives i Codina (1931-1993), botanist and bryologist from Cataluña (Spain), who collected the specimen.

Caulis rigidus pauciramosus. Folia lanceolata recta vix falcata, margine integerrimo incrassato ad quater-stratoso, sectione elliptica omnia cellulae similes inter se, costa crassa apice excedens. Foliorum cellulis laevis. Caetera ignota.

Plants robust, growing in brownish- or olive-green, not very dense tufts, rather rigid and stiff in appearance. Stems (2-)4-6 cm long, hardly branched, light brown or greenish, attached to the substratum only at base with reddish-brownish smooth rhizoids; in cross-section irregularly rounded, $0.25-0.4 \mathrm{~mm}$ in diameter, hyalodermis absent, with 2-3 layers of superficial small cells with incrassate walls, central strand absent. Leaves hardly altered, erect, slightly incurved or secund, especially in the more distal parts of stems when dry, erect-patent when moist, lanceolate, straight or slightly falcate, not keeled, symmetrical at lower part, $(2.8-) 3-3.4 \times 0.75-0.85 \mathrm{~mm}$, very little narrowed at base, here 0.65-0.8 $\mathrm{mm}$ wide. Lamina unistratose except at margins; apex flat, acute; leaf margins strong, robust, 4-6 cells wide, entire, plane, thickened from base to apex, where confluent with the costa; in transverse section elliptical, with 0-2 layers of internal cells not much differentiated from the outer ones, in longitudinal section inner cells rectangular with more or less rounded ends, 8-10 $\times 25-40 \mu \mathrm{m}$. Costa stout, 170180(-230) $\mu \mathrm{m}$ wide at leaf base, gradually narrowed to the apex, here $40-50 \mu \mathrm{m}$ wide, excurrent in a thick mucro, (60-)90-130(-150) $\mu \mathrm{m}$ long, ventral and dorsal cells of the costa quadrate to shortly rectangular near the leaf apex, $10 \times 10(-12.5) \mu \mathrm{m}$, becoming rectangular towards the leaf base, here $7.5 \times 30(-42.5) \mu \mathrm{m}$; in transverse section elliptical near base, becoming roundish towards the apex, with 8-10 guide cells at base and 4-5 guide cells at apex, always in 1 layer, 2 stereid bands, dorsal and ventral epidermic cells differentiated. Laminal cells quadrate, roundish or variously polygonal to shortly rectangular, 8.75-12.5 × 10-15(-17.5) $\mu \mathrm{m}$, smooth, at leaf base some cells rectangular, to 20-30 $\mu \mathrm{m}$ long, with more incrassate walls, smooth; some marginal cells clearly rectangular, sometimes forming 1-2 incomplete longitudinal rows, 8.75-12.5 $\times 12.5$ $20(-25) \mu \mathrm{m}$, smooth. Sterile.

\section{Discussion}

This new species differs from Cinclidotus fontinaloides (as it was previously identified) in several features. These include its rigid appearance, with erect, slightly incurved or secund (not curled), flat (not keeled) leaves when dry that are lanceolate, 


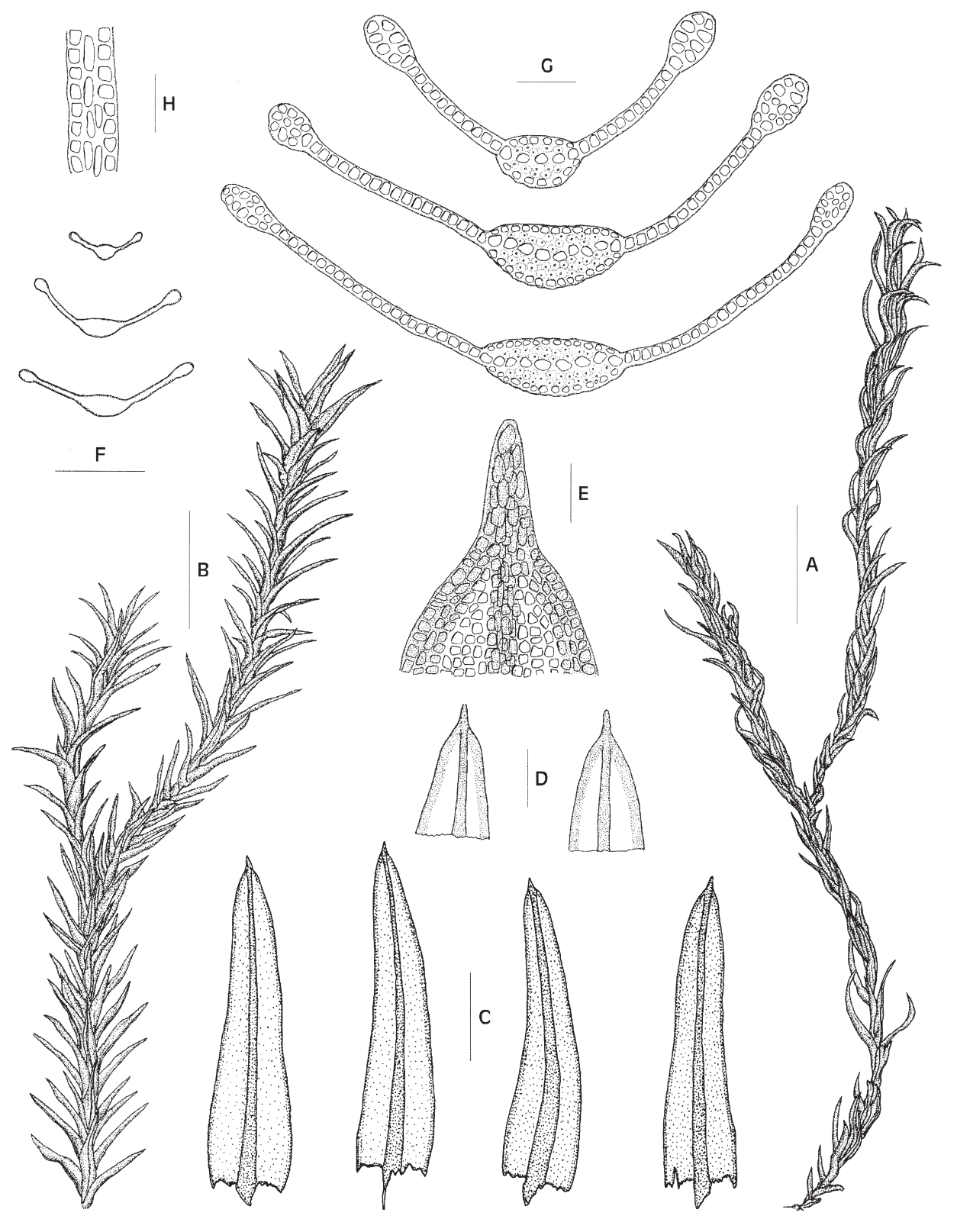

Fig. 1. Cinclidotus vivesii (All from isotype). A: habit when dry; B: habit when wet; C: leaves; D, E: leaf apices; F, G: cross-sections of leaves; H: longitudinal section of leaf margin. Bars: A, B = 4,5 $\mathrm{mm} ; \mathrm{C}=0,8 \mathrm{~mm} ; \mathrm{E}=65 \mu \mathrm{m} ; \mathrm{F}=0,4 \mathrm{~mm} ; \mathrm{G}=60 \mu \mathrm{m} ; \mathrm{H}=50 \mu \mathrm{m}$.

slightly falcate and symmetrical at base, a costa ending in an excurrent mucro, and the structure of the leaf margins, which are elliptical in cross-section, with little or 
no differentiation in size between inner and superficial cells. On the contrary, Cinclidotus fontinaloides has leaves that are frecuently curled when dry, oblong-lanceolate, assymetrical at base, and somewhat keeled, and the leaf margins are rounded in crosssection with the inner cells being very different in size from the superficial cells.

The structure of the leaf margins of Cinclidotus vivesii look like that of some forms of Cinclidotus riparius (Blockeel 1998), but again the rigid aspect of the plants when dry, the leaf shape and the stout and plane apex of Cinclidotus vivesii make that species different. Additionally, Cinclidotus vivesii has leaves with a stout costa, 170$180 \mu \mathrm{m}$ wide at base, while that of Cinclidotus riparius never exceeds $140 \mu \mathrm{m}$.

Cinclidotus vivesii and Cinclidotus aquaticus may appear similar because of the rigid aspect and the leaf shape, but they are quite different: the new species has smaller and far less falcate leaves with thicker margins than Cinclidotus aquaticus. Besides, the costa of Cinclidotus aquaticus is very stout, 250-400 $\mu \mathrm{m}$ at base, occupying one third or more of the leaf base, and shows, in cross-section, 1-2 layers of differentiated subepidermical cells.

The main differences with Cinclidotus danubicus Schiffner \& Baumgartner are the leaf shape and the strength and length of the thickened leaf margins, which are thicker in Cinclidotus vivesii. The margins of the leaves in Cinclidotus danubicus are not more than two cells thick (Schiffner \& Baumgartner 1906) and disappear almost always well below the leaf apex (typus W!), while in Cinclidotus vivesii the margin can be as much as four cells thick and it is confluent with the costa at the leaf apex.

The excurrent costa in a mucro of Cinclidotus vivesii might remind one of other species, such as Cinclidotus pachyloma E.S.Salmon (Salmon 1900), C. nyholmiae Çetin (Çetin 1988) and C. pachylomoides Bizot (Bizot et al. 1952), but all these three species have papillose cells and stronger leaf margins among other different features.

Although the herbarium label of the sample is quite sparse in terms of habitat data and it only says "Font Gran" (that means "Gran's Spring" or "Great Spring"), the substrate must be calcareous, because the application of $\mathrm{HCl}$ results in numerous bubbles, and the plant must have been collected while submerged in water, because its surface is partially covered by large quantities of diatoms and blue-green algae.

\section{Acknowledgments}

We would like to thank the curators of Iberian herbaries for sending us material on loan, specially Dra. Brugués of BCB (Universidad Autónoma de Barcelona) where the new species was kept and curators of BM, W, STU, G and NY for kindly allowing us to study Cinclidotus types. We would like to thank William R. Buck for valuable comments on the manuscript. This work was carried out with financial support from MCYT of Spain, Projects BOS2000-0296-C03-01, BOS2000-0296C03-02 and REN2003-00766/GLO.

\section{References}

BIZOT, M., R. GAUME \& R. POTIER DE LA VARDE (1952): Une poignée de Mousses libanaises - Rev. Bryol. Lichénol. 21: 11-13. 
BLOCKEEL, T.L. (1998): Cinclidotus riparius re-instated as a British and Irish moss - J. Bryol. 20: 109-119.

CASAS, C. (1991): New check-list of Spanish mosses - Orsis 6: 3-26.

CASAS, C. (1995): Modificaciones a "New check-list of Spanish Mosses II" - Bol. Soc. Esp. Briol. 6: 5-6.

CASAS, C. (1996): Modificaciones a "New check-list of Spanish Mosses III" - Bol. Soc. Esp. Briol. 9: 8-10.

CASAS, C. (1999): Modificaciones a "New check-list of Spanish Mosses IV" - Bol. Soc. Esp. Briol. 14: 13-15.

ÇETIN, B. (1988): Cinclidotus nyholmiae, a new species from Köprülü Canyon National Park (Antalya) in Turkey - J. Bryol. 15: 269-273.

SALMON, E.S. (1900): Bryological Notes - Rev. Bryol. 4: 59-60.

SCHIFFNER, V. \& J. BAUMGARTNER (1906): Über zwei neue Laubmoosarten aus Österreich Österr. Bot. Zeitschr. 56: 154-159.

www.einstein.uab.es (2005): Llista de les molses d'Espanya i les Illes Balears. Segons Casas (1991). Actualizat.

Received 8 June 2005, accepted in revised form 4 July 2005. 